Ethos: Jurnal Penelitian dan Pengabdian Masyarakat, Vol 9 No.1, Januari 2021: 118-122

\title{
Pendampingan Optimalisasi Pemanfaatan lahan Pekarangan Rumah SEbAGai TEMPaT TANAMAN BARU AQUAPONIK
}

\author{
${ }^{1}$ Zuhrotul hasanah, ${ }^{2}$ Tony Yulianto, ${ }^{3}$ Ira Yudistira \\ ${ }^{1,2,3,}$ Fakultas MIPA, Jurusan Matematika, Universitas Islam Madura, Jawa Timur, Indonesia \\ email: ${ }^{1}$ ukhtizuhro@gmail.com; ${ }^{2}$ toniyulianto65@gmail.com; ${ }^{3}$ Irayudistira91@gmail.com
}

\begin{abstract}
Food needs are the most important basic human needs in rural communities. Generally in rural communities whose income as farmers. With the development of the times, the land in the countryside has almost diminished and the settlements are starting to narrow. During this time Pondok Kecil Aba Ali Wafa planted several plants in his yard but the yard was narrow so could not grow more vegetables. So to solve the problem is made assistance related to the utilization of yard land using aquaponics, in the hope that the plants can be more even though the yard is narrow but can produce many plants. People can use the narrow land to be a very easy source of search. Vegetables will be more controlled from pest and vegetable disorders more naturally not mixed by inorganic fertilizers. The results achieved after aquaponics reached $30 \%$.
\end{abstract}

Keywords: aquaponics, yardland, optimization

\begin{abstract}
Abstrak. Kebutuhan pangan merupakan kebutuhan dasar manusia yang paling utama pada masyarakat pedesaan. Umumnya pada masyarakat pedesaan yang penghasilannya sebagai petani. Dengan berkembangnya zaman, tanah di pedesaan sudah hampir berkurang dan pemukiman yang mulai sempit. Selama ini Pondok Kecil Aba Ali Wafa menanam beberapa tanaman dipekarangannya namun pekarangannya lahannya sempit sehingga tidak bisa menanam sayur lebih banyak. Maka untuk mengatasi masalah tersebut dibuat pendampingan terkait pemanfaatan lahan pekarangan menggunakan aquaponik, dengan harapan tanamannya bisa lebih banyak meskipun pekarangannya sempit tetapi bisa menghasilkan banyak tanaman.Masyarakat bisa memanfaatkan lahan yang sempit menjadi sumber pencarian yang sangat mudah. Sayuran akan lebih terkontrol dari gangguan hama dan sayur lebih alami tidak tercampur oleh pupuk anorganik. Hasil yang dicapai setelah dilakukan aquaponik mencapai $30 \%$.
\end{abstract}

Kata Kunci: aquaponik, lahan pekarangan, optimalisasi

\section{Pendahuluan}

Sayur dan ikan merupakan sumber vitamin dan mineral. Konsumsi sayuran dan ikan masyarakat indonesia juga mengalami peningkatan. Pertumbuhan ini berkaitan erat dengan peningkatan kesadaran masyarakat untuk hidup sehat serta peningkatan dan adanya indikasi bakteri Salmonella dan E.coli pada sayuran dan ikan dapat dijadikan suatu pertimbangan untuk budidaya sayuran dan ikan yang berkualitas dan higienis. Selain itu, semakin terbatasnya lahan pertanian dan air terutama di perkotaan dan lingkungan pemukiman padat mengakibatkan kekhawatiran para petani sirnanya mata pencarian. Diperlakukan teknik budidaya yang dapat menghemat lahan dan air, sehingga dapat menjadi alternatif untuk menanami sayuran pada lahan sayuran terbatas disertai dengan beternak ikan (Ferijal, Jayanti, \& Nurba, 2017).

Selama ini Pondok Kecil Aba Ali Wafa menanam beberapa tanaman dipekarangannya namun pekarangannya 
lahannya sempit sehingga tidak bisa menanam sayur lebih banyak. Maka untuk mengatasi masalah tersebut dibuat pendampingan terkait pemanfaatan lahan pekarangan menggunakan aquaponik, dengan harapan tanamannya bisa lebih banyak meskipun pekarangannya sempit tetapi bisa menghasilkan banyak tanaman. Masyarakat bisa memanfaatkan lahan yang sempit menjadi sumber pencarian yang sangat mudah. Peningkatan kesejahteraan keluarga dapat dilaksanakan melalui budidaya tanaman sayur-sayuran, tanaman buah pot dan ikan dipekarangan.

Aquaponik merupakan perpaduan antara akuakultur (budidaya ikan) dengan hidroponik (budidaya tanaman tanpa tanah, tetapi memanfaatkan air bernutrisi) dengan menggunakan berupa kolam terpal, drum plastik, kolam fiberglass atau tandon air. Aquaponik tanaman ditahan di dalam pipa dengan menggunakan rodwold yang terpisah dari tangki ikan. Aquaponik memiliki kemampuan untuk memproduksi protein, sehingga pemanfaatan aquaponik dapat memanen sayuran dan ikan dari satu wadah dalam waktu yang bersamaan (Ferijal, Jayanti, \& Nurba, 2017).

Saat ini menanam dengan sistem aquaponik adalah alternantif yang tepat untuk mendapatkan sayuran dan buahbuahan di lahan yang sempit atau terbatas. Sistem aquaponik memiliki keuntungan diantaranya adalah tanaman aquaponik dapat dilakukan pada lahan yang terbatas, selain itu perawatan tanaman pada sistem aquaponik lebih prajtis dan gangguan hama lebih terkontrol (Purwasih \& Evahelda, 2019).

\section{Metode}

Metode yang digunakan yaitu dengan komunikasi tatap muka, diskusi, penyuluhan dan dengan cara demonstrasi langsung dilapangan. Dengan judul "Pendampingan Optimalisasi Pemanfaatan Lahan Pekarangan Rumah Sebagai Tempat Tanaman Baru Aquaponik".

\section{Waktu dan Tempat Pelaksanaan}

Pengabdian masyarakat ini dilakukan di Lembaga Pondok Kecil Aba Ali Wafa dusun Barat desa Teja Barat Pamekasan Jawa Timur pada tanggal 17-23 Agustus 2020

\section{Metode dan Rancangan Pengabdian}

1. Tahapan Awal

Tahapan awal dilakukan selama dua hari. Hari pertama melakukan diskusi dengan masyarakat untuk mengetahui permasalahan yang dihadapi dan mendiskusikan rencana untuk mengatasi masalah yang dihadapi. Dan hari kedua pengambilan bahan berupa bibit sayur sebagai media tanaman, lele sebagai organisme, pipa untuk media aquaponik, pompa air, pellet ikan sebagai pakan ikan lele, sayur sawi atau bayam, dan kawat dari bahan tersebut merupakan persiapan untuk tahap pelaksanaan kegiatan.

2. Tahapan Pelaksanaan

Tahapan pelaksanaan dilakukan selama 3 hari. Hari pertama yaitu komunikasi kepada masyarakat dan memberikan penyuluhan mengenai konteks konsep aquaponik dan memberikan pelatihan menajemin produksi dan pasca produksi.

Hari kedua masyarakat langsung praktek mengenai sistem pembuatan aquaponik. Tahap dilakukan dalam Pembuatan kolam ikan. Hari ketiga penyusunan pipa air, 
melubangi pipa air untuk tempat bibit sayur, penempatan pompa air kolam ikan supaya pemakaian aerator akan lebih optimal dan tenaga kerja akan lebih hemat. Selain itu menggunakan sistem bionic (bio natural and aquaponic combination) dapat mengatasi bau air kolam dan kandungan nutrisi dari sisa makanan dan kotoran ikan akan tetap dapat digunakan (Fathir \& Hasanah, 2020).

3. Tahapan monitoring dan Evaluasi

Tahapan ini dilakukan selama dua hari. Hari pertama mengecek bibit sayur yang sudah mulai tumbuh daun. Hari kedua menempatkan bibit yang mulai tumbuh daun kedalam rodwold (tempat untuk bibit). Namun ada pemilihan bibit yang memang dipilih untuk dimasukkan kedalam pipa seperti bibit sudah mulai tumbuh 3 daun yang masih kecil-kecil. Jika masih belum tumbuh daun maka belum bisa di masukkan kedalam pipa aquaponik.

\section{Pengambilan Sampel}

Pengambilan sampel mengambil dari sayur aquaponik yang sudah mulai tumbuh dengan kira-kira 80\%.

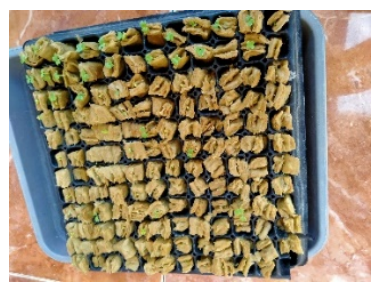

Gambar 1. Sayur Aquaponik

Berdasarkan Gambar 1, hasil sayur aquaponik sudah bisa dikonsumsi dan bisa diperjual-belikan.

\section{Hasil dan Pembahasan}

Dari hasil dan pembahasan dapat diperoleh dalam tahap pertama pertumbuhan bibit sayur mulai tumbuh. Ada yang hanya tumbuh 1 daun, 2 daun dan 3 daun.

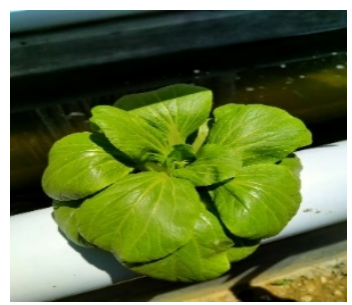

Gambar 2. Bibit sayur yang sudah tumbuh daun-daun sayur.

Berdasarkan Gambar 2 bibit sayur yang sudah mulai tumbuh 3 daun sudah bisa diletakkan di dalam rodwol. sedangkan Daun Sayur yang sudah lebih berkembang sudah bisa dikonsumsi atau diperjual belikan.

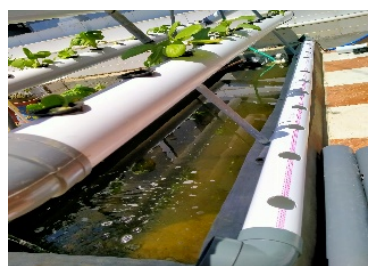

Gambar 3. Daun sayur yang sudah diambil

Berdasarkan Gambar 3, merupakan sayur yang sudah diambil daunnya, walaupun daunnya sudah diambil namun masih bisa tumbuh kembali, akan tetapi hasil daunnya tidak sama dengan hasil pertama. Bedanya daun akan lebih kecil dan tidak sebagus hasil pertama. 


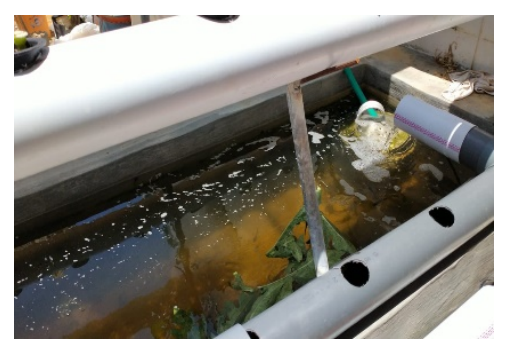

Gambar 4. Ikan lele berukuran $6 \mathrm{~cm}$.

Berdasarkan Gambar 4 dalam penanamannya sayur aquaponik ini mengandalkan ikan lele. Dalam menyediakan makanan organik dan nutrisi untuk membantu tanaman tumbuh. Tanaman dapat membersihkan, menyaring dan mendaur ulang air kembali ke ikan sehingga akan tercipta hubungan simbiosis. Aquaponik dapat dianggap sebagai integrasi dari dua teknologi produksi yang relatif mapan: resirkulasi sistem akuakultur dimana limbah ikan dirawat dan dibersihkan sebelum dikembalikan ke tangki ikan: dan sistem hortikultura berbasis nutrisi hidroponik (atau kurang tanah). Baik tanaman dan ikan memanfaatkan timbah nutrisi yang dihasilkan oleh ikan. Prinsip kerjanya mempunyai kemiripan dengan akuarium air tawar dimana tanaman dan ikan ditanam (Sari \& Ariyanto, 2020).

Dari hasil yang diperoleh dapat disimpulkan pada diagram yang ditunjukkan pada gambar 5 .

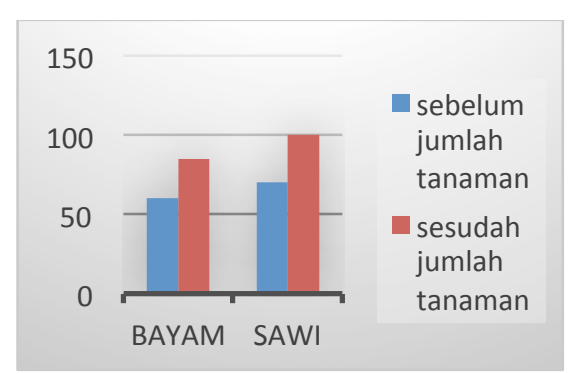

Gambar 5. Diagram sebelum dan

sesudah jumlah tanaman

Berdasarkan Gambar 5, ternyata bayam setelah dilakukan aquaponik memiliki keuntungan sekitar 25\% lebih baik dari pada sebelum adanya aquaponik. Sedangkan sawi setelah dilakukan aquaponik memiliki keuntungan sekitar 30\% lebih baik dari pada sebelum adanya aquaponik.

Jadi, ada peningkatan dengan sebelum adanya sistem aquaponik dan sesudah adanya sistem aquaponik. Dari sayurnya saja sudah berbeda dari segi kualitas, sayur lebih empuk, lebih segar dan tidak terkena hama. Sistem aquaponik juga berkaitan erat dengan resirkulasi dari 'pencucian' sampahsampah sisa metabolisme ikan (faces) dan sisa-sisa pakan yang tidak tercerna. Hal ini berkaitan erat dengan siklus nitrogen dann proses nitrifikasi dalam perairan media budidaya ikan (Nugroho, TP, Chilmawati , \& Condro, 2012).

\section{Kesimpulan dan Saran}

Simpulannya , ternyata bayam setelah dilakukan aquaponik memiliki keuntungan sekitar 25\% lebih baik dari pada sebelum adanya aquaponik. Sedangkan sawi setelah dilakukan aquaponik memiliki keuntungan sekitar $40 \%$ lebih baik dari pada sebelum adanya aquaponik. Dan memiliki hasil yang lumayan sudah sangat membantu petani dan masyarakat yang memiliki lahan sempit. Sarannya, selain menggunakan tahap aquaponik, mungkin ditambah dengan menggunakan tahap hidroponik, vertikultur, atau tabulampot.

\section{Ucapan Terima Kasih}

Terima kasih kepada Kepala Lembaga Pondok Kecil Aba Ali Wafa yang sudah memberikan izin mengadakan pelatihan pengabdian kali ini. LPPM dan DPL yang sudah berkenan memberikan arahan dan bimbingan untuk tetap menjaga nama baik almamater dalam proses pelaksanaan KKN Covid-19 UIM tahun 
ajaran 2019/2020. Dan segenap pihak yang bersangkutan dalam pengabdian kali ini.

\section{DAFTAR PUSTAKA}

Ferijal, Jayanti, D. S., \& Nurba, D. (2017). Pemanfaatan Lahan Pekarangan Sempit Dengan Teknologi Aquaponik Dalam Rangka Pemberdayaan Dan Peningkatan Kesejahteraan Masyarakat Gampong Kandang Kecamatan Darul Imarah Kabupaten Aceh Besar. Banda Aceh: Prosiding Seminar Nasional.

Purwasih, R., \& Evahelda. (2019). Pemanfaatan Lahan Pekarangan Untuk Budi Daya Sayuran Hidrponik. Jurnal Ilmiah Pengabdian kepada Masyarakat , 195-201.

Fathir, A., \& Hasanah, S. F. (2020). Penerapan Aquaponik dan Pengembangan Budidaya Ikan Lele Pada Unit Usaha Pondok Pesantren
Kota Malang. Jurnal Laporan Masyarakat , 4 (1), 1-7.

Sari, D. P., \& Ariyanto, D. (2020). Pemanfaatn Lahan Pekarangan Dengan Sistem Aquaponik Dalam Menunjang Perekonomian Di Desa Sungai Lama, Kabupaten Asahan, Sumatera Utara. Jurnal Anadara Pengabdian Kepada Masyarakat , 68-71.

Nugroho, R. a., TP, L., Chilmawati , D., \& Condro, A. (2012). Aplikasi Teknologi Aquaponik Pada Budidaya Ikan Air Tawar Untuk Optimalisasi Kapasitas Produksi. Sainstek Perikanan , 46-51. 